\title{
The Relationship between Organizational Learning at the Individual Level and Perceived Employability: A Model-Based Approach
}

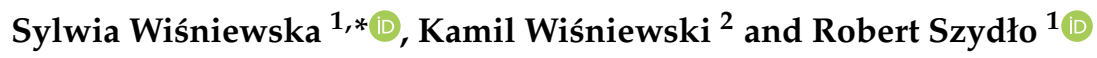 \\ 1 Department of Labor Resources Management, Cracow University of Economics, 31-510 Cracow, Poland; \\ robert.szydlo@uek.krakow.pl \\ 2 Department of Management, The Jan Kochanowski University in Kielce, 25-369 Kielce, Poland; \\ kamil.wisniewski@ujk.edu.pl \\ * Correspondence: sylwia.wisniewska@uek.krakow.pl
}

check for updates

Citation: Wiśniewska, S.; Wiśniewski, K.; Szydło, R. The Relationship between Organizational Learning at the Individual Level and Perceived Employability: A Model-Based Approach. Sustainability 2021, 13, 7561. https://doi.org/ $10.3390 /$ su13147561

Academic Editor: Víctor Jesús García-Morales

Received: 31 May 2021

Accepted: 1 July 2021

Published: 6 July 2021

Publisher's Note: MDPI stays neutral with regard to jurisdictional claims in published maps and institutional affiliations.

Copyright: (c) 2021 by the authors. Licensee MDPI, Basel, Switzerland. This article is an open access article distributed under the terms and conditions of the Creative Commons Attribution (CC BY) license (https:// creativecommons.org/licenses/by/ $4.0 /)$.

\begin{abstract}
The challenges of the modern labor market determine increased job insecurity and the growing importance of sustainable employability. Today, in an era of the growth of the world's knowledge resources, permanent learning is indispensable in order to maintain or strengthen one's employability. Therefore, this article aims to determine the relationship between organizational learning solutions at the individual level and perceived employability in the modern labor market according to the workers' opinions. Studies conducted on the subject literature confirm the lack of research in this field. A survey was conducted among 351 employees from a number of organizations based in Poland and was performed using a computer-assisted web interview (CAWI). The study's results indicate that out of eleven analyzed solutions, people value those connected with sustainable actions the most, such as learning from one's own mistakes (own mistakes), observing other employees' work (observing others), self-education, incentive systems (contributing to an increase in the commitment to competency development), and providing employees with feedback on the results of their work (feedback). Moreover, it is important to state that EFA first revealed, and CFA subsequently confirmed, two factors: Factor 1, Practical Aspects, which includes organizational learning that covered such activities as incentive systems, feedback, self-education, modern technologies, and the use of case studies, and Factor 2, Active Learning, which consists of two activities-one's own mistakes and observing others. The research results lead to the conclusion that Factor 1, Practical Aspects, had a significant impact on perceived employability, while Factor 2, Active Learning, did not have an impact on the general assessment of organizational learning in the context of perceived employability. The authors also present the diamond attempt toward actions that might be taken by organizations in order to enhance the employability of workers in general. The conducted research is considered to be idiographic and exploratory.
\end{abstract}

Keywords: perceived employability; sustainable employability; organizational learning; labor market

\section{Introduction}

Progressing globalization, the increasing scale of migration, global economic crises, digital transformations, and changes in the labor market all mean that employers have been demanding increasingly higher levels of competencies from workers [1-4]. Today, these conditions determine increased job insecurity and the growing importance of sustainable employability in the modern labor market $[5,6]$. Sustainable employability is understood as "individuals' long-term abilities to work and remain employed" [7]. Sustainability is "the use of a resource over time, without the utility value of that resource being negatively and preferably positively affected by its use" [7]. It is worth emphasizing that employability is an important and impactful research subject in the contemporary world [8-10]. Although the notion of employability was introduced into the subject literature in the early 
20th century by Beveridge [11] and became prevalent in the 1990s, in the 21st century, theoreticians and practitioners are still wrestling with the concept [12-14]. Moreover, the current market conditions imply a need for continuous learning and the perpetual development of competencies as the basis for increasing one's employability in the present-day labor market. In an age of constant increases in global knowledge resources, which are subject to obsolescence, organizations are faced with the necessity of enhancing learning process dynamics [15].

Empirical research results indicate that the performance of professional work with a high learning value contributes to employee development [16-18] and to self-perceived employability [19-21]. Importantly, research conducted in the discussed area also indicates that the level of a worker's employability depends on learning in the workplace [22-26]. Furthermore, the results of empirical studies confirm that diversity in worker professional tasks has a positive impact on informal learning, which in turn determines the level of workers' employability [27]. One of the key factors affecting worker employability is lifelong learning $[25,28,29]$. It has also been highlighted that creating opportunities for learning in the workplace facilitates enhanced worker employability in the long term [30]. It is worth noting that preliminary empirical research results indicate that respondents evaluate the importance of organizational learning for the development of employability in the modern labor market to be very high. Conclusions drawn from the research show that the individual level of organizational learning is especially considered highly significant by the respondents $[15,31]$. The results of these pilot studies prompted the authors of this article to undertake exploratory research on the relationship between organizational learning solutions used at the individual level and perceived employability in the modern labor market.

Concluding the above considerations, it is worth noting that in the subject literature, there is a research gap in exploring the relationship between organizational learning solutions used at the individual level and perceived employability in the modern labor market. Therefore, and based on the previous outline, the aim of this article is to determine the relationship between organizational learning solutions at the individual level and perceived employability in the modern labor market, according to the opinions of the workers.

\section{Literature Review}

The term employability is a composite word merging "employ" and "ability" and can be interpreted as the "ability to employ" [5] (p. 3). The subject literature presents various definitions of employability. Employability, in general, is one's ability to be employed [32,33]. A widely cited definition formulated by Van der Heijde and Van der Heijden [34] describes employability as "the continuous fulfilling, acquiring or creating of work through the optimal use of competences". According to McArdle et al. [35], employability is defined as "the ability to gain and maintain employment, both within and across organizations". Similarly, Rothwell and Arnold [36] suggest that employability is "the ability to keep the job one has or to get the job one desires". The importance of developing employability throughout a worker's entire life is reflected in the definition developed by Bennett et al. [8], who define it as "the ability to find, create and sustain meaningful work across the career lifespan". Furthermore, Vanhercke et al. [37], in their definition, indicate the subjective aspect of employability, emphasizing that employability is "the individual's perception of his or her possibilities of obtaining and maintaining employment". Berntson [38] claims that perceived employability, which is a subjective assessment of employability, means "how easy (or difficult) people believe it would be for them to get a new employment". It is worth noting that perceived employability refers to subjective considerations of ability for employment and one's possibilities for employment [39].

It is worth emphasizing that employability contains work-related knowledge and skills that allow for the continuous employment of an individual in the labor market in addition to active adaptability and execution ability, which are used to understand changes in the environment and circumstances and to achieve sustainable employment 
within them [5]. Therefore, employability is understood as the ability to exploit one's own potential to maintain sustainable employment security [33]. Moreover, in the subject literature, it is emphasized that employability is the result of the combination of knowledge, skills, and ability to change these resources and to adapt to new conditions $[40,41]$.

Measures of employability involve both subjective and objective dimensions. A subjective dimension discusses the individual perception of one's possibilities of obtaining and maintaining sustainable employment suitable to one's level of competencies [42]. In turn, an objective dimension refers to the individual's ability to obtain and maintain employment either in the present organization or with a different employer $[43,44]$.

In connection with the above considerations, it is worth noting that employability is a multidimensional construct with objective and subjective elements that is studied from both an individual perspective $[41,42,45]$ and an organizational perspective $[29,46]$. The issue of employability is also considered at the macroeconomic level [11,47]. Moreover, the level of employability determines the individual's situation in the labor market and affects the person's chances of career success [35]. It is worthwhile to add that employability has a future-oriented and dynamic nature, in contrast to employment, which adopts a static perspective [43].

Van Raemdonck [48], inspired by Pollet et al. [49] and Landau et al. [50], identified three components of employability: “(1) An employable person is a person who takes learning initiatives, (2) is able to remain employed (job tenure), and (3) is able to obtain new employment after being unemployed or as the result of active career planning (career realizations)". These components are considered as indicators of employability and emphasize the importance of learning in developing employability in the modern labor market.

There are numerous factors that may impact one's employability. Hillage and Pollard [33] claim that employability depends on the individual's personal and external circumstances and the inter-relationship between them. McQuaid and Lindsay [51] propose a multidimensional approach to individual employability, including the following three dimensions: individual factors, personal circumstances, and external factors. Wiśniewska [52] suggests that employability is conditioned by various factors, including demand side, supply side, or mixed (demand and supply side). Demand-related factors include, among others, the demand for labor, the labor market capacity, and attitudes of employers towards the unemployed. Supply side determinants include, among others, the size of the labor supply as well as organizational and individual factors. Mixed determinants, in turn, can be represented by the structure and policies of the labor market. Almeida [53] proposed that employability is a result of the interaction between the individual and the labor market. It is worth noting that individual factors that impact the self-perception of employability include, among others, individual knowledge and skills acquired through formal or informal learning as well as through work experience [54-56].

The popularity of the concept of organizational learning is a consequence of seeking new opportunities for creating competitive advantage based on the knowledge of organizations and their employees [57]. In building a knowledge-based economy, organizational learning might be classified as one of the primary factors in employee development, including their employability [15]. Learning and employability seem to be highly related and complementary research constructs [58,59], but they lack a clear understanding mainly due to limited research focus on these two concepts and their association.

In general, organizational learning is defined as a process of the generation, transfer, and/or modification of knowledge carried out by an organizational member and/or groups of members in order to improve organizational outcomes and performance [60]. Organizational learning is also defined as "a learning process within organizations that involves the interaction of individual and collective (group, organizational, and inter-organizational) levels of analysis and leads to achieving organizations' goals" [61]. Organizational learning is considered to be an effective strategy for enhancing and maintaining a company's sustainable performance improvements and competitive advantage in the market [62]. In the strategic management literature, organizational learning is described as a systematic 
change in organizational behavior as a result of new knowledge that the organization creates by sharing former experiences [63-65]. Organizational learning is also understood as an experience-driven change process in the organizational knowledge base [63]. Organizational learning is considered a process rather than a set of capabilities [66]. Moreover, the process of organizational learning is performed by the concurrent processes of the verification of existing knowledge and the development of new knowledge, and unlearning is part of learning here [67]. It is worth emphasizing that organizational learning is a process that "links cognition and action" [68] and is, therefore, a fundamental framework for creating and adapting changes in organizations [69]. Organizational learning is enormously important in an organization because it is associated with the process of creating value from an organization's intangible assets. Furthermore, it combines notions from several various domains, such as human resource management, organizational behavior, artificial intelligence, and information technology [70].

The process of organizational learning occurs at various levels, i.e., individual, team, organizational, and interorganizational [31,71-75]. Organizational learning at the individual level involves processes occurring in employee minds, which result in the creation and modification of individual knowledge connected with working in a given organization (this knowledge determines the performance of professional tasks by particular employees). The result of learning at this level is the deepening of knowledge by employees, which they should use both for their own professional development and the organization's development [76-79]. Next, at the team level, learning concerns processes which are effects of interactions between employees who form a given team. These processes are oriented towards group problem solving and decision making, which provide a basis for subsequent joint operation [61,76-79]. Learning at the next level, i.e., organizational, relates to changes occurring in elements such as organizational structure, strategy of operations, or organizational culture. Learning at this level results in institutionalized knowledge of the organization, consolidated under the aforementioned elements [76,80]. Finally, learning at the interorganizational level takes place while cooperating with stakeholders functioning in the organization's environment $[81,82]$. The individual level of organizational learning presented above was analyzed in the conducted survey, which allowed an empirical exemplification of the discussed theoretical issues. Organizational learning solutions at the individual level analyzed in the exploratory research were selected on the basis of the subject literature $[15,31]$ (Figure 1). 
Interorganizational level

Organizational level

Team level

Individual level

Solutions:

(1) Own mistakes

(2) Observing others

(3) Self-education

(4) Incentive system

(5) Feedback

(6) Participation

(7) Modern technologies

(8) Knowledge acquisition

(9) Information transfer

(10) Use of case study

(11) Job rotation

Figure 1. Conceptual model of the individual level of organizational learning in the context of perceived employability based on $[15,31]$.

\section{Materials and Methods}

In order to achieve the aim of the article, two research questions were formulated. The first was: what organizational learning solutions used at the individual level are the most important in developing workers' employability? Apart from describing the individual level of organizational learning, it was possible to formulate a hypothesis about its impact on employability:

Hypothesis 1 (H1). Employees perceive that organizational learning at the individual level has an impact on their employability.

The second question was connected with personal characteristics that affect perceived employability. Due to the lack of prior publications, there was no hypothesis introduced by the authors, but an exploratory study was performed to confirm areas such as gender, age, education level, workplace, professional status, work experience, company size, company profile, and generation.

For the needs of the research, it was assumed that perceived employability is one's perception of his or her opportunities for taking, maintaining, and changing employment and developing a professional career in the internal and external labor market, resulting from both individual and contextual factors. Moreover, in the conducted research, organizational learning was understood as the process of the acquisition, generation, development, and use of knowledge by employees in response to the organization's mission and objectives as well as to market challenges. This study focused on the part of organizational learning at the individual level and covered topics from the perspective of employees $[31,71,73,74]$. The research analyzed the following organizational learning solutions applied at the individual level: (1) learning from one's own mistakes (own mistakes); (2) observing other 
employees' work (observing others); (3) self-education; (4) incentive system (including financial and nonfinancial instruments, contributing to an increase in the commitment to competency development); (5) providing employees with feedback on the results of their work (feedback); (6) employee participation in codeciding on the learning areas connected with specific tasks and objectives (participation); (7) application of modern technologies in the learning process (modern technologies); (8) acquisition of knowledge by informal contact with clients, suppliers, etc. (knowledge acquisition); (9) transfer of information from the environment to the organization's knowledge bases (information transfer); (10) use of case study; and (11) job rotation [15,31].

There was also a need to operationalize other possible variables. Gender was coded on a dichotomic scale (Women, Men) with the possibility of not answering this question. Age was coded in years. The educational level was an eight-level ordinal variable that represents the types of education that one is allowed to achieve in Poland, namely primary, vocational, secondary, secondary technical, postsecondary, bachelor's degree, master's degree, and "other", which was the classification for any answer that was outside the provided categories. Workplace was understood as hierarchical levels forming the organizational structure of the enterprises, namely the positions of manager, team leader, specialist position, and others. Professional status was described as the sector-based variable: public sector, private sector, entrepreneur, and others. Work experience was measured in years. Company profile was introduced to research participants as industrial, services, mixed, and others. The size of the company was described as large, medium, small, and micro according to the classification presented by OECD [83]. The generations were classified as a comparison of various approaches that resulted in categories such as Boomers (1943-1960), Generation X (1961-1981), Generation Y (1982-1995), Generation Z (1996-2010) [15].

The survey was conducted among 351 employees from a number of organizations based in Poland and was performed with the use of a computer-assisted web interview (CAWI). The statistical analysis of the study results was conducted using the IBM (Armonk, NY, USA) Predictive Solution 6 and IBM AMOS for SEM.

\subsection{Applied Statistical Methods}

Several statistical methods were introduced in the research procedure, described below in chronological order of usage. The main were EFA and CFA. Exploratory factor analysis (EFA) was conducted in order to identify the factor structure of variables and decrease their number by identifying the metalevel $[84,85]$. The maximum likelihood extraction method within the CFA maximizes the reliability of the parameters and, as such, minimalizes the discrepancy function [86]:

$$
F_{M L}=\log \left|\sum(0)\right|+\operatorname{tr}\left(S \sum(0)^{-1}\right)-\log |S|-q
$$

where $S$ = covariance and variance matrix calculated from $\mathrm{N}$-element test, $\sum(0)=$ covariance and variance matrix resulting from the model, $0=$ vector of model parameters, and $q=$ number of observable variables. Even though the research samples do not meet the multivariate normal distribution condition, the authors decided to use that statistic because the $M L$ estimator is treated as robust and resistant [87] for the lack of normality.

Confirmatory factor analysis (CFA) was applied to check the internal validity of the model of employee perspectives on organizational learning, created within the covariancebased structural equation modeling (CB-SEM). Confirmative factor analysis serves to test hypotheses that can be formulated in accordance with this model [88]:

$$
x_{j}=a_{j 1} f_{1}+\ldots+a_{j k} f_{k}+d_{j} u_{j}+\delta_{j}
$$

where $x_{j}$-j-variable $(j=1, \ldots, \mathrm{m}), f_{1}, \ldots, f_{k}$-common factors, $a_{j 1}, \ldots, a_{j k}$-loads of common factors, $u_{j}$-specific factor, $d_{j}$-load of specific factor, and $\delta_{j}$-random component. It was important to prove that the model created with EFA could be fully trusted. Apart 
from the two main tools, Cronbach's alpha coefficient, CFI, RMSEA, and PCLOSE were also calculated to confirm the results.

\subsection{Collecting Data and Research Sample}

The questionnaire, mostly composed of close-ended questions in the form of so-called table questions or scale questions, was developed on the basis of the literature review. Particular questions in the questionnaire were constructed based on the Likert scale with the following answer choices: 0-a given solution is not important to 7-very high importance. In the questionnaire, there was also the possibility to indicate that a given solution was not applicable.

The questionnaire used in the research was presented to the respondents in four parts: definitions of organizational learning and employability, assessment of the perceived impact of organizational learning on employability, general perceived impact, and personal data.

The original questionnaire for assessing the perceived importance of organizational learning solutions at the individual level in developing worker employability, as presented in the conceptual model (Figure 1), which was used in this research, was characterized by high reliability. The Cronbach's alpha reliability coefficient, where reliability is understood as the internal consistency of a tool, was 0.957 for the whole sheet and ranged between 0.714 to 0.914 for particular measurements. Therefore, all items of the general scale as well as the particular subscales were considered reliable and were included in the questionnaire. A statistical analysis of the findings was performed using IBM Predictive Solution 6 and IBM AMOS for SEM.

Purposive sampling was applied in the research in order to maintain the structure of education levels among employees [89] excluding physical workers-as such, there are not many organizational learning determinants used for this kind of employee. A diagnostic survey was carried out among employees from a number of organizations operating in Poland. Between September and November of 2019, a pilot study was conducted, which led to questionnaire verification and necessary adjustments. The main study was conducted between March and May of 2020. It involved 351 working individuals, including 274 women $(78.1 \%)$ and 77 men $(21.9 \%)$, in the age range of 19 to 64 years old. The respondents had 1 to 40 years of work experience. They represented the following education levels: basic vocational -3 people $(0.9 \%)$, secondary general -55 people $(15.7 \%)$, secondary technical62 people $(17.6 \%)$, postsecondary -12 people $(3.4 \%)$, higher undergraduate -118 people $(33.5 \%)$, higher engineering - 15 people $(4.3 \%)$, higher graduate -81 people $(23.1 \%)$, and Ph.D. -5 people $(1.5 \%)$. The participants were employed at enterprises of various sizes: micro—73 people $(20.8 \%)$, small—97 people $(27.6 \%)$, medium -66 people $(18.8 \%)$, and large-115 (32.8\%). The research also involved representatives of various generations present in the labor market: Baby Boomers (5.7\%), Generation X (8.5\%), Generation Y $(53.8 \%)$, and Generation Z (30.08\%), while four people did not admit their age.

The empirical research was conducted in accordance with ethical standards. The participants volunteered to participate in the research. As it was performed on the basis of the CSAQ made with the use of Google (Mountain View, CA, USA) forms, each participant had to agree to participate in the research by selecting the appropriate answer before taking part in the research. The questionnaire did not collect any email addresses or personal data that allowed for identifying the respondents. Each respondent was also informed about the possibility of freely withdrawing from the research at any time. The questionnaire was located on a secured G-SUIT drive, to which only researchers had access, in accordance with the EU General Data Protection Regulation.

\section{Results}

To obtain the answer to the first research question, based on the organizational learning solutions at the individual level, respondents were asked to assess 11 different activities supporting organizational learning in the context of employability. The Cronbach's alpha 
reliability coefficient, where reliability is understood as the internal consistency of this scale, was equal to 0.908 . The mean value for the general assessment of this level (individual level) was equal to $\mathrm{M}=5.38, \mathrm{SD}=1.443$. The results of each of the criteria given are presented in Table 1.

Table 1. Descriptive statistics of the individual level determinants (each determinant is coded with the letter "I" and number in brackets).

\begin{tabular}{cccc}
\hline Specification & N & Mean & Std. Deviation \\
\hline Own mistakes (I6) & 341 & 5.51 & 1.360 \\
Observing others (I7) & 345 & 5.39 & 1.318 \\
Self-education (I1) & 345 & 5.24 & 1.536 \\
Incentive system (I11) & 331 & 5.23 & 1.672 \\
Feedback (I3) & 335 & 5.23 & 1.455 \\
Participation (I8) & 325 & 5.05 & 1.447 \\
Modern technologies (I4) & 331 & 5.05 & 1.553 \\
Knowledge acquisition (I2) & 336 & 5.02 & 1.508 \\
Information transfer (I10) & 329 & 4.79 & 1.461 \\
Use of case study (I9) & 316 & 4.76 & 1.586 \\
Job rotation (I5) & 320 & 4.32 & 1.569 \\
Valid N (listwise) & 265 & & \\
\hline
\end{tabular}

According to the respondents, eight activities received a mean value higher than 5.0. Two of them received a score of more than 5.3, namely own mistakes (I6), with ( $\mathrm{M}=5.51$, $\mathrm{SD}=1.360)$, and observing others $(\mathrm{I} 7)$, with $(\mathrm{M}=5.39, \mathrm{SD}=1.318)$. Three of the activities were scored below 5.0. Those were: information transfer (I10), with $(\mathrm{M}=4.79, \mathrm{SD}=1.461)$; use of case study (I9), with $(\mathrm{M}=4.76, \mathrm{SD}=1.586)$; and job rotation (I5), for which the lowest was recorded, with $(\mathrm{M}=4.32, \mathrm{SD}=1.569)$.

In order to ease the research procedure, an exploratory factor analysis (EFA) was performed, utilizing principal component analysis as an extraction method and varimax rotation. The EFA revealed two factors. The results of the analysis are shown in Table 2.

Table 2. Exploratory factor analysis—rotated component matrix for the individual level.

\begin{tabular}{ccc}
\hline Specification & \multicolumn{2}{c}{ Factor } \\
\cline { 2 - 3 } & $\mathbf{1}$ & $\mathbf{2}$ \\
\hline Incentive system (I11) & 0.747 & 0.274 \\
Feedback (I3) & 0.706 & 0.242 \\
Self-education (I1) & 0.681 & 0.262 \\
Modern technologies(I4) & 0.680 & 0.314 \\
Use of case study (I9) & 0.656 & 0.381 \\
Participation (I8) & 0.617 & 0.533 \\
Information transfer (I10) & 0.614 & 0.528 \\
Knowledge acquisition (I2) & 0.596 & 0.313 \\
Job rotation (I5) & 0.301 & 0.301 \\
Observing others (I7) & 0.233 & 0.837 \\
Own mistakes (I6) & 0.282 & 0.575 \\
\hline
\end{tabular}

Extraction Method: Maximum Likelihood. Rotation Method: Varimax with Kaiser Normalization. Rotation converged in 3 iterations.

Factor 1, Practical Aspects, gathered activities such as incentive system (I11), feedback (I3), self-education (I1), modern technologies (I4), use of case study (I9), participation (I8), information transfer (I10), knowledge acquisition (I2), and job rotation (I5). The Cronbach's alpha for Factor 1, Practical Aspects, can be considered as very good, $\alpha=0.898$.

Factor 2, Active Learning, grouped activities such as own mistakes and observing others, both of which are focused on active gathering of knowledge. The Cronbach's alpha for Factor 2, Active Learning, can be considered as acceptable, $\alpha=0.702$. 
In order to confirm the results, confirmatory factor analysis was performed based on CB-SEM methodology and IBM AMOS. The created model is shown in Figure 2.

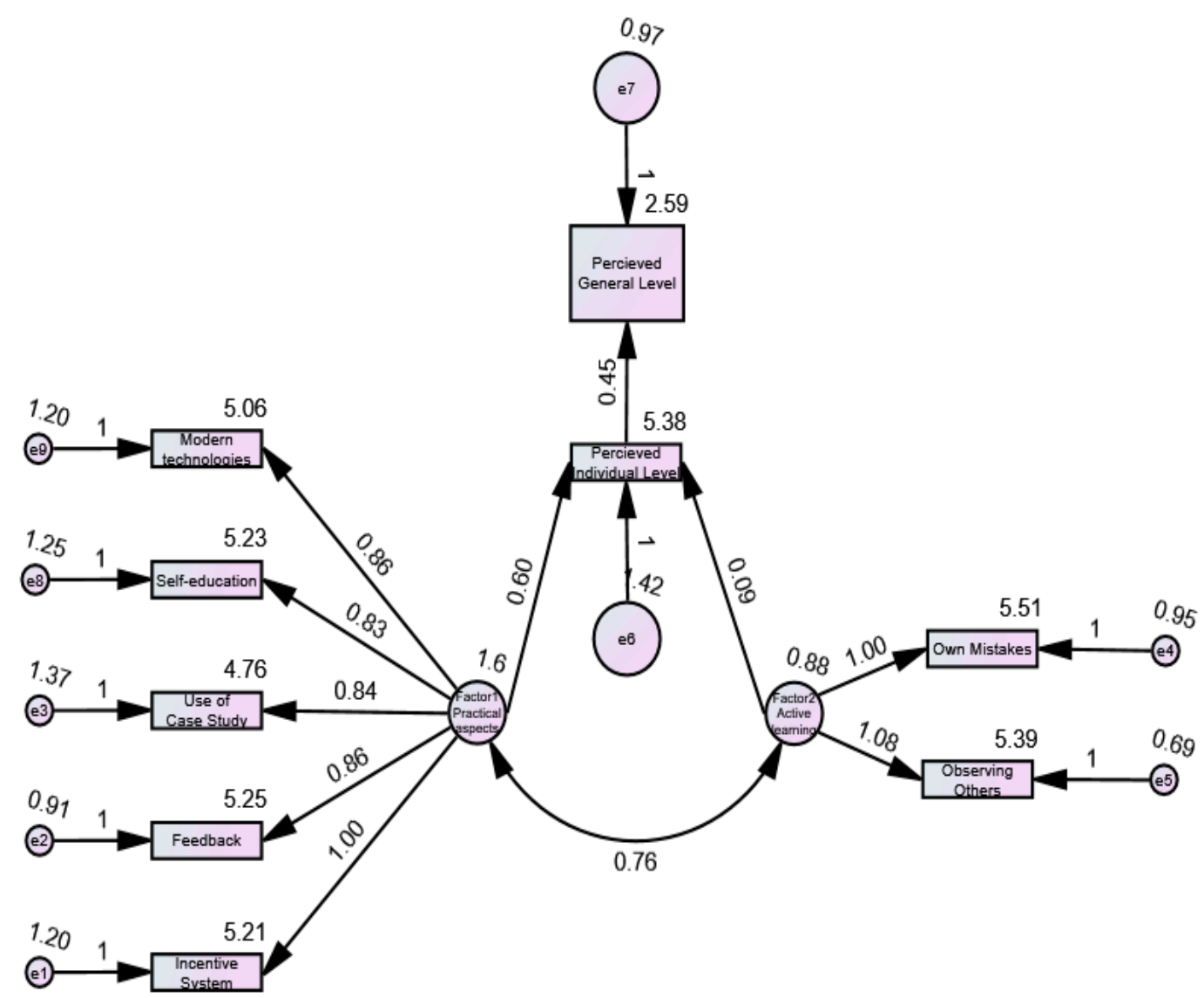

Figure 2. Model of the individual level in the context of organizational learning with standardized estimates.

For Factor 1, Practical Aspects, five determinants were matched. They all received more than 0.656 of an impact on the first factor itself. These were incentive system (I11), feedback (I3), self-education (I1), modern technologies (I4), and use of case study (I9). It is important to state that although the EFA revealed Factor 1, Practical Aspects, with nine manifested variables, the authors decided to reject four of them. The variable job rotation (I5) achieved loading equal to 0.301 , which is considered as insignificant [90,91], and what is more, variable job rotation was loading both factors on the same level. The variables knowledge acquisition (I2) - loading 0.596, information transfer (I10)—loading 0.614 , and participation (I8)-loading 0.617 were also rejected because of dissatisfactory loadings, as satisfactory loading of a factor in EFA is considered to be greater than or equal to 0.65 [92,93]. Furthermore, CFA models created with nine variables presented dissatisfactory fit parameters-CFI $<0.9$, RMSEA $>0.1$, and PCLOSE $<0.05$, in most of the cases. The presented model manifested the most accurate fit parameters.

For Factor 2, Active Learning, two determinants were matched. Both of them scored more than 0.575 of an impact on the second factor itself. These were: own mistakes (I6) and observing others (I7). The numerical results of confirmatory factor analysis are presented in Table 3. 
Table 3. Confirmatory factor analysis—the individual level.

\begin{tabular}{cccccccc}
\hline & & & Estimate & S.E. & C.R. & $p$ & Label \\
\hline Employee & $<-$ & Factor1_Practical_aspects & 0.597 & 0.092 & 6.506 & $* * *$ & par_8 \\
Employee & $<-$ & Factor2_Active_learning & 0.089 & 0.125 & 0.710 & 0.477 & par_9 \\
I11 & $<-$ & Factor1_Practical_aspects & 1.000 & & & & \\
I3 & $<-$ & Factor1_Practical_aspects & 0.856 & 0.066 & 12.898 & $* * *$ & par_1 \\
I9 & $<-$ & Factor1_Practical_aspects & 0.836 & 0.074 & 11.368 & $* * *$ & par_2 \\
I7 & $<-$ & Factor2_Active_learning & 1.084 & 0.132 & 8.237 & $* * *$ & par_3 \\
I6 & $<-$ & Factor2_Active_learning & 1.000 & & & & \\
General & $<-$ & Employee & 0.451 & 0.037 & 12.306 & $* * *$ & par_5 \\
I1 & $<-$ & Factor1_Practical_aspects & 0.832 & 0.070 & 11.910 & $* * *$ & par_6 \\
I4 & $<-$ & Factor1_Practical_aspects & 0.860 & 0.071 & 12.108 & $* * *$ & par_7 \\
\hline$* * *$ - $<<0.001 .<-$ & - dependence direction. & & & & &
\end{tabular}

Most of the relations presented in a model were statistically significant. The impact of Factor 1, Practical Aspects, for the assessment of perceived determinants of employability that are connected with organizational learning at the individual level (Perceived Individual Level) was equal to $0.596, p<0.001$. On the other hand, the impact of Factor 2, Active Learning, was equal to 0.089 , but with $p=0.477$, it was not statistically significant. There was a strong positive correlation between both factors, equal to $r=0.76, p<0.001$. The presented model was tested for accuracy. As the result of the analysis, the following indicators were presented: $\mathrm{CMIN} / \mathrm{DF}=2.153 ; \mathrm{CFI}=0.973 ; \mathrm{RMSEA}=0.057$; and $\mathrm{PCLOSE}=0.261$. All the above values prove the model to be accurate and well fitted.

To verify the hypothesis about the positive impact of perceived determinants of employability that are connected with organizational learning on the perceived general level, the results of the CFA were equal to $0.451, p<0.001$, which allowed us to positively verify the hypothesis.

As only Factor 1, Practical Aspects, had a positive impact on the perceived employability at the individual level of organizational learning, the normality of distribution was declined $W_{(294)}=0.946, p<0.001$. The statistical inference results performed with the nonparametric tests for the exploratory study are presented in Table 4.

Table 4. Results of testing.

\begin{tabular}{ccccc}
\hline Aspect & $\begin{array}{c}\text { U Mann-Whitney/ } \\
\text { H Kruskal-Wallis Statistics/ } \\
\text { R Spearman's }\end{array}$ & df & $p$-Level & Decision \\
\hline Gender & $\mathrm{U}=7175.5$ & - & 0.882 & No significance \\
Age & $\mathrm{R}=0.092$ & - & 0.059 & No significance \\
Education level & $\mathrm{H}=2.256$ & 6 & 0.894 & No significance \\
Workplace & $\mathrm{H}=6.349$ & 3 & 0.96 & No significance \\
Work experience & $\mathrm{R}=0.082$ & - & 0.082 & No significance \\
Professional status & $\mathrm{H}=4.936$ & 3 & 0.177 & No significance \\
Company size & $\mathrm{H}=3.231$ & 3 & 0.357 & No significance \\
Company profile & $\mathrm{H}=0.474$ & 3 & 0.924 & No significance \\
Generation & $\mathrm{H}=3.114$ & 2 & 0.374 & No significance \\
\hline
\end{tabular}

The conducted analysis allowed the answer to the second research question to be obtained. Among all the researched aspects, none of them made a statistically significant difference in terms of the perceived impact of determinants of organizational learning at the individual level on employability.

\section{Discussion and Conclusions}

The researchers analyzed the relationship between organizational learning solutions at the individual level and perceived employability in the modern labor market, according to the opinions of the workers surveyed. The study's results indicate that out of eleven 
analyzed solutions, people value most those connected with sustainable actions, such as learning from one's own mistakes, observing other employees' work, self-education, incentive systems, contributing to an increase in the commitment to competency development, and providing employees with feedback on the results of their work. All of these solutions scored more than 5.2 in the survey, which stood for rather high assessment.

It is also important to state that EFA first revealed, and CFA then confirmed, two factors. Factor 1, Practical Aspects of organizational learning, covered such activities as incentive system, feedback, self-education, modern technologies, and the use of case study. The Factor 2, Active Learning, consisted of two activities: own mistakes and observing others. Factor 1, Practical Aspects, had a significant impact on the employability measured at the individual level of organizational learning. The processes forming Factor 1, Practical Aspects, assume the conscious incompetence level from the Four Levels of Teaching Model by Broadwell [94], also used by Mayer et al. [95], and the support in learning processes ensured by technology. Incentive processes also act as the reason for learning that may be described by a fourth "practice stage" of Kolb's cycle [96].

At the individual level, activities connected with active learning did not have an impact on a general assessment of organizational learning in the context of employability. It was an interesting fact and may be connected with the characteristics of adult learning. Kolb [97] set the canon of the andragogic approach for learning by creating a cycle of four ways of learning. According to the research results, only step one was presented, which is called "experience". People observe the work of other employees and can see that they made a mistake themselves, but there is no drive to conduct the following steps of the theory, such as reflection, conceptualization, or future usage - there is a lack of active approach towards learning [98]. Lack of impact might also be explained by the competency matrix introduced by Davis [99]. In this approach, even though people can observe working conditions and the way others perform tasks, they may not see the logic behind them or the real usage at work, and as such, they will not undertake any actions to overcome these obstacles. In other words, there is a lack of drive made by organization specialists to support these activities by ensuring an understanding of the process of learning its steps and the practical implications of learning.

An interesting outcome may be presented. The five elements that merge in Factor 1, Practical Aspects, might be presented in the form of a diamond (Figure 3).

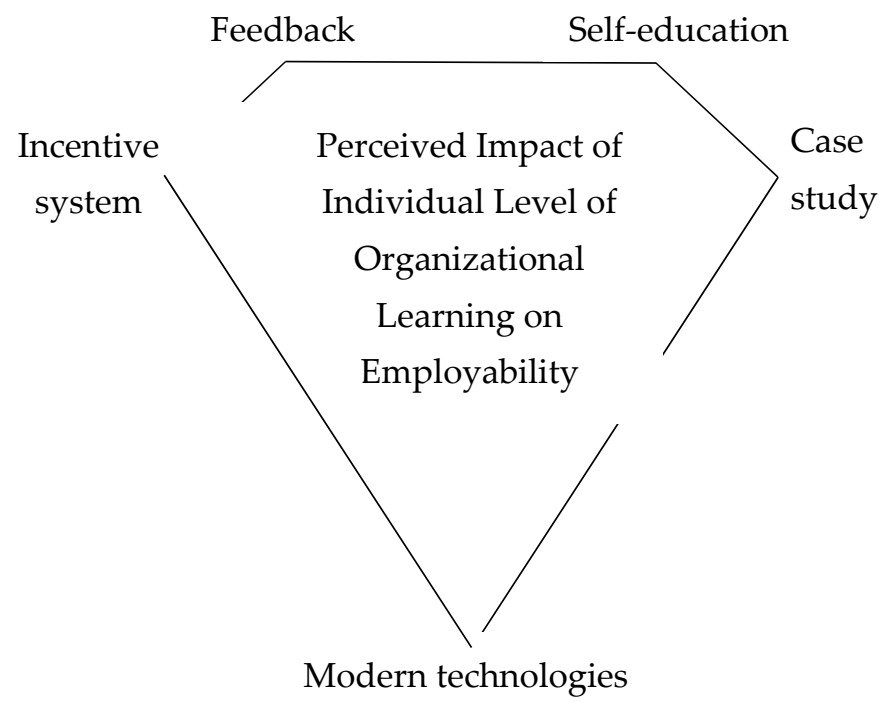

Figure 3. Graphic presentation of Factor 1 Practical Aspects.

Based on the hypothesis verification, it is important to state that it is not only lifelong learning $[100,101]$ and general organizational learning $[15,31]$ that may strongly correlate with employability. It is important to determine which exact actions may benefit employa- 
bility. The highest importance at the individual level of organizational learning relates to a properly shaped incentive system, providing employees with feedback on the results of their work, self-education of employees, and the use of case studies in the learning process as well as application of modern technologies in learning, which corresponds very well with the requirements of a knowledge-based economy and Industry 4.0 [102-104].

A properly shaped incentive system, including financial and nonfinancial instruments, contributes to an increase in commitment to competency development and is important in maintaining and increasing employability in the modern labor market. The importance of the motivation to learn in developing employability is emphasized by Tentama et al. [23]. Tymon [105] also claims that the motivation to learn has a positive effect on the level of employability. Feedback is also a widely discussed topic in the context of employability. Gerken et al. [106] prove that receiving feedback from colleagues is an important aspect of building employees' employability, as are feedback loops from leaders [107], especially when the feedback relates to current performance [108]. It is worth mentioning that self-education is also considered as a factor enhancing employability in today's society [109]. This is confirmed by the results of empirical studies [20,27]. Furthermore, keeping workers' competencies up to date through self-education is important for their employability because competency demands a constant change in response to organizational and technological innovations [110]. Therefore, it is important to use modern technologies in the learning process. In an educational context, modern technologies have the potential to increase access to education and improve its quality and relevance [111]. The digital transformation has proved that e-learning systems are to become a crucial platform for educational institutions and various organizations as well as for general life-long learning $[112,113]$. In addition, an essential importance in the learning process is assigned to the use of case studies. The case study is one of the most effective methods of learning because this method enables one to acquire the knowledge and skills to deal with the problem. People are working on and creating solutions to real-life situations similar to the situations they are working with $[114,115]$.

The results of the study complement the gap in knowledge regarding the relationship between organizational learning solutions at the individual level and perceived employability in the modern labor market. The conducted studies of the subject literature confirm the lack of research in this field.

The presented research may have practical implications in two fields. The first of them relates to science. It may serve as a base for future in-depth, explanatory research. The second practical implication relates to company management. Knowing that employees perceive the impact of the exact determinants of the individual level of organizational learning, HR specialists and managers may focus on just five main activities: incentive systems, feedback, self-education, modern technologies, and case studies, because those are the activities that are most connected with the development of employability by workers. In the context of the present findings, it is worth mentioning that a human resource development strategy should consist of formal and informal learning. The mix of formal and informal learning is presumably the best way to maintain and enhance workers' employability in the modern labor market.

\subsection{Limitations}

There are a few limitations within the research procedure and sample. The conducted research is considered to be idiographic and exploratory. The authors are aware of the limited generalization possibility of the research. However, they are an empirical exemplification of the undertaken research problem. Another limitation is that the research sample was also not properly balanced since it was dominated by women, people from Generation $\mathrm{Y}$, and people working in services from the private sector. All these characteristics did not allow for the use of parametric testing and, at the same time, makes the generated conclusions not fully adequate and advanced. It is important to state that this research 
was just an exploration of the perceived impact of the individual level of organizational learning on employability.

\subsection{Future Research}

Future in-depth research in the context of current limitations should be conducted in the discussed area among a larger number of respondents in order to develop comprehensive recommendations for business practice. A detailed analysis of the effectiveness of individual solutions in the field of organizational learning in developing worker employability also seems justified. This would significantly enrich the results of the empirical research presented in this article.

It is within the plans of the authors to examine and prepare an analysis not only at the individual level of organizational learning in terms of perceived employability but also focused on both team and organizational levels as well as at the interorganizational level.

Author Contributions: Conceptualization, S.W.; methodology, S.W., K.W. and R.S.; software, R.S.; formal analysis, S.W.; investigation, S.W. and K.W.; resources, S.W. and K.W.; data curation, S.W., K.W. and R.S.; writing-original draft preparation, S.W., K.W. and R.S.; writing-review and editing, S.W.; funding acquisition, S.W. and R.S. All authors have read and agreed to the published version of the manuscript.

Funding: The research has been carried out as part of a research initiative financed by the Ministry of Science and Higher Education within the "Regional Initiative of Excellence" Programme for 2019-2022. Project No.: 021/RID/2018/19. Total financing: PLN 11,897,131.40.

Informed Consent Statement: Informed consent was obtained from all subjects involved in the study.

Data Availability Statement: The data presented in this study are available on request from the corresponding author. The data are not publicly available due to the in-progress work on another paper with this data.

Conflicts of Interest: The authors declare no conflict of interest.

\section{References}

1. Aprianti, V.; Sahid, S. The relationship between teachers' competency and fourth industrial revolution (4ir) learning among economics teachers. Univers. J. Educ. Res. 2020, 8, 63-70. [CrossRef]

2. Chen, C.-H.; Yang, C.-K.; Huang, K.; Yao, K.-C. Augmented reality and competition in robotics education: Effects on 21st century competencies, group collaboration and learning motivation. J. Comput. Assist. Learn. 2020, 36, 1052-1062. [CrossRef]

3. Faina, I.; Almeida, F. Key competencies for digital transformation in workplace. In Knowledge, People, and Digital Transformation: Approaches for a Sustainable Future (Contributions to Management Science), 1st ed.; Matos, F., Vairinhos, V., Salavisa, I., Edvinsson, L., Massaro, M., Eds.; Springer: Cham, Germany, 2020; pp. 219-234.

4. Raghuram, S.; Hill, N.S.; Gibbs, J.L.; Maruping, L.M. Virtual work: Bridging research clusters. Acad. Manag. Ann. 2019, 13, 308-341. [CrossRef]

5. Kwon, J.E. Work volition and career adaptability as predictors of employability: Examining a moderated mediating process. Sustainability 2019, 11, 7089. [CrossRef]

6. Martínez-Cerdá, J.-F.; Torrent-Sellens, J.; González-González, I.; Ficapal-Cusí, P. Opening the black-box in lifelong e-learning for employability: A framework for a socio-technical e-learning employability system of measurement (STELEM). Sustainability 2018, 10, 1014. [CrossRef]

7. Fleuren, B.P.; de Grip, A.; Jansen, N.W.H.; Kant, I.J.; Zijlstra, F.R.H. Unshrouding the sphere from the clouds: Towards a comprehensive conceptual framework for sustainable employability. Sustainability 2020, 12, 6366. [CrossRef]

8. Bennett, D.; Knight, E.; Rowley, J. The role of hybrid learning spaces in enhancing higher education students' employability. Br. J. Educ. Technol. 2020, 51, 1188-1202. [CrossRef]

9. Magnano, P.; Santisi, G.; Zammitti, A.; Zarbo, R.; di Nuovo, S. Self-perceived employability and meaningful work. The mediating role of courage on quality of life. Sustainability 2019, 11, 764. [CrossRef]

10. Peeters, E.; Nelissen, J.; de Cuyper, N.; Forrier, A.; Verbruggen, M.; de Witte, H. Employability capital: A conceptual framework tested through expert analysis. J. Career Dev. 2019, 46, 79-93. [CrossRef]

11. Beveridge, W.H. Unemployment: A Problem of Industry, 1st ed.; Longmans, Green \& Co.: London, UK, 1909.

12. Herbert, I.P.; Rothwell, A.T.; Glover, J.L.; Lambert, S.A. Graduate employability, employment prospects and work-readiness in the changing field of professional work. Int. J. Manag. Educ. 2020, 18, 100378. [CrossRef]

13. Midtsundstad, T. A review of the research literature on adult learning and employability. Eur. J. Educ. 2019, 54, 13-29. [CrossRef] 
14. Olivares, S.L.; Adame, E.; Treviño, J.I.; López, M.V.; Turrubiates, M.L. Action learning: Challenges that impact employability skills. High. Educ. Skills Work Based Learn. 2019, 10, 203-216. [CrossRef]

15. Wiśniewska, S. Organizational learning and employability in enterprises: Preliminary empirical research results. Hum. Resour. Manag. 2020, 134-135, 61-73. [CrossRef]

16. DeRue, D.S.; Wellman, N. Developing leaders via experience: The role of developmental challenge, learning orientation, and feedback availability. J. Appl. Psychol. 2009, 94, 859-875. [CrossRef] [PubMed]

17. Dragoni, L.; Tesluk, P.E.; Russell, J.E.A.; Oh, I.-S. Understanding managerial development: Integrating developmental assignments, learning orientation, and access to developmental opportunities in predicting managerial competencies. Acad. Manag. J. 2009, 52, 731-743. [CrossRef]

18. Berings, M.G.M.C.; Poell, R.F.; Simons, P.R.-J. Dimensions of on-the-job learning styles. Appl. Psychol. 2008, 57, 417-440. [CrossRef]

19. Van der Heijden, B.; Spurk, D. Moderating role of LMX and proactive coping in the relationship between learning value of the job and employability enhancement among academic staff employees. Career Dev. Int. 2019, 24, 163-186. [CrossRef]

20. Van der Heijden, B.; Boon, J.; van der Klink, M.; Meijs, E. Employability enhancement through formal and informal learning: An empirical study among Dutch non-academic university staff members. Int. J. Train. Dev. 2009, 13, 19-37. [CrossRef]

21. Van der Heijden, B.I.J.M.; de Lange, A.H.; Demerouti, E.; van der Heijde, C.M. Age effects on the employability-career success relationship. J. Vocat. Behav. 2009, 74, 156-164. [CrossRef]

22. Gabor, M.R.; Blaga, P.; Matis, C. Supporting employability by a skills assessment innovative tool: Sustainable transnational insights from employers. Sustainability 2019, 11, 3360. [CrossRef]

23. Tentama, F.; Subardjo; Abdillah, M.H. Motivation to learn and social support determine employability among vocational high school students. Int. J. Eval. Res. Educ. 2019, 8, 237-242. [CrossRef]

24. Van der Heijden, B.I.J.M.; Gorgievski, M.J.; de Lange, A.H. Learning at the workplace and sustainable employability: A multisource model moderated by age. Eur. J. Work Organ. Psychol. 2016, 25, 13-30. [CrossRef]

25. Sparrhoff, G.R. Learning for employability: Managers' self-governance and learning in organizational practices. Procedia Soc. Behav. Sci. 2012, 46, 3350-3355. [CrossRef]

26. Clarke, M.; Patrickson, M. The new covenant of employability. Empl. Relat. 2008, 30, 121-141. [CrossRef]

27. Froehlich, D.E.; Segers, M.; Beausaert, S.; Kremer, M. On the relation between task-variety, social informal learning, and employability. Vocat. Learn. 2019, 12, 113-127. [CrossRef]

28. Urbaniak, B. Imperatyw kształcenia ustawicznego w gospodarce opartej na wiedzy. In Podstawy Kształcenia Ustawicznego od A do Z. Monografia, 1st ed.; Znajmiecka-Sikora, M., Roszko, E., Eds.; Wydawnictwo Ego: Łódź, Poland, 2010; pp. 15-42.

29. Nauta, A.; van Vianen, A.; van der Heijden, B.; van Dam, K.; Willemsen, M. Understanding the factors that promote employability orientation: The impact of employability culture, career satisfaction, and role breadth self-efficacy. J. Occup. Organ. Psychol. 2009, 82, 233-251. [CrossRef]

30. Opengart, R.; Short, D.C. Free agent learners: The new career model and its impact on human resource development. Int. J. Lifelong Educ. 2002, 21, 220-233. [CrossRef]

31. Wiśniewska, S.; Wiśniewski, K. Organizacyjne uczenie się jako determinanta zatrudnialności pracowników. Przeg. Org. 2020, 20-27. [CrossRef]

32. Finn, D. From full employment to employability: A new deal for Britain's unemployed? Int. J. Manpow. 2000, 21, 384-399. [CrossRef]

33. Hillage, J.; Pollard, E. Employability: Developing a Framework for Policy Analysis, 1st ed.; Department for Education and Employment: London, UK, 1998.

34. Van der Heijde, C.M.; van der Heijden, B.I.J.M. A competence-based and multidimensional operationalization and measurement of employability. Hum. Resour. Manag. 2006, 45, 449-476. [CrossRef]

35. McArdle, S.; Waters, L.; Briscoe, J.P.; Hall, D.T. Employability during unemployment: Adaptability, career identity and human and social capital. J. Vocat. Behav. 2007, 71, 247-264. [CrossRef]

36. Rothwell, A.; Arnold, J. Self-perceived employability: Development and validation of a scale. Pers. Rev. 2007, 36, 23-41. [CrossRef]

37. Vanhercke, D.; de Cuyper, N.; Peeters, E.; de Witte, H. Defining perceived employability: A psychological approach. Pers. Rev. 2014, 43, 592-605. [CrossRef]

38. Berntson, E. Employability Perceptions: Nature, Determinants, and Implications for Health and Well-Being, 1st ed.; Department of Psychology, Stockholm University: Stockholm, Sweden, 2008.

39. Berntson, E.; Marklund, S. The relationship between perceived employability and subsequent health. Work Stress 2007, 21, 279-292. [CrossRef]

40. Yorke, M.; Knight, P.T. Embedding Employability into the Curriculum: Learning \& Employability Series I, 1st ed.; The Higher Education Academy: York, UK, 2006.

41. Fugate, M.; Kinicki, A.J.; Ashforth, B.E. Employability: A psycho-social construct, its dimensions, and applications. J. Vocat. Behav. 2004, 65, 14-38. [CrossRef]

42. Rothwell, A.; Herbert, I.; Rothwell, F. Self-perceived employability: Construction and initial validation of a scale for university students. J. Vocat. Behav. 2008, 73, 1-12. [CrossRef]

43. Cortellazzo, L.; Bonesso, S.; Gerli, F.; Batista-Foguet, J.M. Protean career orientation: Behavioral antecedents and employability outcomes. J. Vocat. Behav. 2020, 116, 103343. [CrossRef] 
44. Lysova, E.I.; Jansen, P.; Khapova, S.N.; Plomp, J.; Tims, M. Examining calling as a double-edged sword for employability. J. Vocat. Behav. 2018, 104, 261-272. [CrossRef]

45. Fugate, M.; Kinicki, A.J. A dispositional approach to employability: Development of a measure and test of implications for employee reactions to organizational change. J. Occup. Organ. Psychol. 2008, 81, 503-527. [CrossRef]

46. De Vos, A.; de Hauw, S.; van der Heijden, B.I.J.M. Competency development and career success: The mediating role of employability. J. Vocat. Behav. 2011, 79, 438-447. [CrossRef]

47. Gazier, B. An Analysis of Employability in the Context of Globalisation in the European Union: Background Paper, 1st ed.; European Commission: Brussels, Belgium; Japanese Ministry of Health, Labour and Welfare: Tokyo, Japan; The Japan Institute for Labour Policy and Training: Tokyo, Japan, 2006.

48. Van Raemdonck, I. Self-Directedness in Learning and Career Processes: A Study in Lower-Qualified Employees in Flanders, 1st ed.; Ghent University, Faculty of Psychology and Educational Sciences: Ghent, Belgium, 2006.

49. Pollet, I.; de Weerdt, Y.; van Hootegem, G.; de Witte, H. Pizza's, Software en Jobs? Laaggeschoold en Dienstverlenend: Met. Hoeveel Zijn ze, wat Doen ze? 1st ed.; HIVA-K.U. Leuven: Leuven, Belgium, 2000.

50. Landau, J.C.; Shamir, B.; Arthur, M.B. Predictors of willingness to relocate for managerial and professional employees. J. Organ. Behav. 1992, 13, 667-680. [CrossRef]

51. McQuaid, R.W.; Lindsay, C. The concept of employability. Urban. Stud. 2005, 42, 197-219. [CrossRef]

52. Wiśniewska, S. Zatrudnialność-Pojęcie, wymiary, determinanty. Eduk. Ekon. Menedż. 2015, 1, 11-24. [CrossRef]

53. Almeida, A.J. Employability, work contexts and labour market in Portugal. Sísifo Educ. Sci. J. 2007, 2, 51-58.

54. Froehlich, D.; Aasma, S.; Beausaert, S. Achieving employability as we age: The role of age and achievement goal orientations on learning and employability. Adm. Sci. 2020, 10, 49. [CrossRef]

55. Van der Klink, M.; van der Heijden, B.I.J.M.; Boon, J.; van Rooij, S.W. Exploring the contribution of formal and informal learning to academic staff member employability: A Dutch perspective. Career Dev. Int. 2014, 19, 337-356. [CrossRef]

56. Knight, P.T.; Yorke, M. Employability through the curriculum. Tert. Educ. Manag. 2002, 8, 261-276. [CrossRef]

57. Chadwick, I.C.; Raver, J.L. Motivating organizations to learning: Goal orientation and its influence on organizational learning. J. Manag. 2015, 41, 957-986. [CrossRef]

58. Knight, P.T.; Yorke, M. Assessment, Learning and Employability, 1st ed.; Society for Research into Higher Education \& Open University Press: Maidenhead, UK, 2003.

59. Knight, P.T.; Yorke, M. Employability and good learning in higher education. Teach. High. Educ. 2003, 8, 3-16. [CrossRef]

60. Real, J.C.; Roldán, J.L.; Leal, A. From entrepreneurial orientation and learning orientation to business performance: Analyzing the mediating role of organizational learning and the moderating effects of organizational size. Br. J. Manag. 2014, 25, 186-208. [CrossRef]

61. Popova-Nowak, I.V.; Cseh, M. The meaning of organizational learning: A meta-paradigm perspective. Hum. Resour. Dev. Rev. 2015, 14, 299-331. [CrossRef]

62. Tortorella, G.L.; Vergara, A.M.C.; Garza-Reyes, J.A.; Sawhney, R. Organizational learning paths based upon industry 4.0 adoption: An empirical study with Brazilian manufacturers. Int. J. Prod. Econ. 2020, 219, 284-294. [CrossRef]

63. Argote, L.; Miron-Spektor, E. Organizational learning: From experience to knowledge. Organ. Sci. 2011, 22, 1123-1137. [CrossRef]

64. Miner, A.S.; Bassof, P.; Moorman, C. Organizational improvisation and learning: A field study. Adm. Sci. Q. 2001, 46, 304-337. [CrossRef]

65. Levitt, B.; March, J.G. Organizational learning. Ann. Rev. Soc. 1988, 14, 319-340. [CrossRef]

66. Pettit, K.; Crossan, M.; Vera, D. Organizational learning and knowledge processes: A critical review. In The SAGE Handbook of Process Organization Studies, 1st ed.; Langley, A., Tsoukas, H., Eds.; SAGE: London, UK, 2016; pp. 481-496.

67. De Holan, P.M.; Phillips, N. Organizational forgetting. Handbook of organizational learning and knowledge management. In Organizational Learning and the Learning Organization: Developments in Theory and Practice; Easterby-Smith, M., Burgoyne, J., Araujo, L., Eds.; SAGE: London, UK, 2011; pp. 433-451.

68. Crossan, M.M.; Lane, H.W.; White, R.E. An organizational learning framework: From intuition to institutionalization. Acad. Manag. Rev. 1999, 24, 522-537. [CrossRef]

69. Benn, S.; Edwards, M.; Angus-Leppan, T. Organizational learning and the sustainability community of practice: The role of boundary objects. Organ. Environ. 2013, 26, 184-202. [CrossRef]

70. El Kadiri, S.; Grabot, B.; Thoben, K.D.; Hribernik, K.; Emmanouilidis, C.; von Cieminski, G.; Kiritsis, D. Current trends on ICT technologies for enterprise information systems. Comput. Ind. 2016, 79, 14-33. [CrossRef]

71. Zgrzywa-Ziemak, A.; Walecka-Jankowska, K. The relationship between organizational learning and sustainable performance: An empirical examination. J. Workplace Learn. 2020, 33. [CrossRef]

72. Lin, H.-C.; Lee, Y.-D. A study of the influence of organizational learning on employees' innovative behavior and work engagement by a cross-level examination. Eurasia J. Math. Sci. Technol. Educ. 2017, 13, 3463-3478. [CrossRef]

73. Gherardi, S. Organizational learning: The sociology of practice. In Handbook of Organizational Learning and Knowledge Management, 2nd ed.; Easterby-Smith, M., Lyles, M.A., Eds.; John Wiley and Sons: Chichester, UK, 2011; pp. $43-66$.

74. Weldy, T.G.; Gillis, W.E. The learning organization: Variations at different organizational levels. Learn. Organ. 2010, 17, 455-470. [CrossRef]

75. Örtenblad, A. The learning organization: Towards an integrated model. Learn. Organ. 2004, 11, 129-144. [CrossRef] 
76. Mahmoudi, G.; Rahimi, V.; Fani, F.; Jahani, M.A.; Mahmoudjanloo, S. A comparison of the levels of organizational learning in hospitals, based on ownership types: A case study in Iran. Gazi Med. J. 2018, 29, 303-307. [CrossRef]

77. Zgrzywa-Ziemak, A. Istota organizacyjnego uczenia się. In Rozwój Zdolności Uczenia się Przedsiębiorstwa, 1st ed.; Zgrzywa-Ziemak, A., Kamiński, R., Eds.; Difin: Warsaw, Poland, 2009; pp. 11-38.

78. Sysko-Romańczuk, S.; Platonoff, A.L.; Rudawska, A. Koncepcja organizacyjnego uczenia się-Podstawowe perspektywy badawcze. Ekon. Org. Przed. 2007, 2, 3-12.

79. Mikuła, B. Modele przedsiębiorstwa przyszłości. In Zarządzanie Przedsiębiorstwem XXI Wieku: Wybrane Koncepcje i Metody, 1st ed.; Mikuła, B., Pietruszka-Ortyl, A., Potocki, A., Eds.; Difin: Warsaw, Poland, 2002; pp. 9-19.

80. Chou, S.Y.; Ramser, C. A multilevel model of organizational learning: Incorporating employee spontaneous workplace behaviors, leadership capital and knowledge management. Learn. Organ. 2019, 26, 132-145. [CrossRef]

81. Morland, K.V.; Breslin, D.; Stevenson, F. Development of a multi-level learning framework. Learn. Organ. 2019, 26, 78-96. [CrossRef]

82. Jones, O.; Macpherson, A. Inter-organizational learning and strategic renewal in SMEs: Extending the 4I framework. Long Range Plann. 2006, 39, 155-175. [CrossRef]

83. OECD. Entrepreneurship at a Glance 2017, 5th ed.; OECD Publishing: Paris, France, 2017. Available online: https: / /www.oecdilibrary.org/industry-and-services/entrepreneurship-at-a-glance_22266941 (accessed on 27 February 2020).

84. Norris, M.; Lecavalier, L. Evaluating the use of exploratory factor analysis in developmental disability psychological research. J. Autism Dev. Disord. 2010, 40, 8-20. [CrossRef] [PubMed]

85. Bryant, F.B.; Yarnold, P.R. Principal-components analysis and exploratory and confirmatory factor analysis. In Reading and Understanding Multivariate Statistics, 1st ed.; Grimm, L.G., Yarnold, P.R., Eds.; American Psychological Association: Washington, DC, USA, 1995; pp. 99-136.

86. Hoyle, R.H. (Ed.) Structural Equation Modeling: Concepts, Issues, and Applications, 1st ed.; Sage Publications, Inc.: Thousand Oaks, CA, USA, 1995.

87. Trzpiot, G. (Ed.) Wybrane Elementy Statystyki Odpornej, 1st ed.; Wydawnictwo Uniwersytetu Ekonomicznego w Katowicach: Katowice, Poland, 2013.

88. Brown, W. Some experimental results in the correlation of mental abilities. Br. J. Psychol. 1910, 3, 296-322. [CrossRef]

89. GUS. 2021. Available online: https://bdl.stat.gov.pl/BDL (accessed on 23 April 2021).

90. Banaszuk, P. Identyfikacja procesów kształtujących skład chemiczny małego cieku w krajobrazie rolniczym na podstawie analizy czynnikowej. Woda Środ. Obsz. Wiej. 2004, 4, 103-116.

91. Evans, C.D.; Davies, T.D.; Wigington, P.J.; Tranter, M.; Kretser, W.A. Use of factor analysis to investigate processes controlling the chemical composition of four streams in Adirondack Mountains, New York. J. Hydrol. 1996, 185, 297-316. [CrossRef]

92. Maciel, E.; Savay-da-Silva, L.K.; Vasconcelos, J.S.; Galvão, J.A.; Sonati, J.; Silva, D.; Oetterer, M. Application of exploratory factor analysis to assess fish consumption in a university community. Food Sci. Technol. Int. 2013, 33, 99-106. [CrossRef]

93. Todd, P.A.; Ladle, R.J.; Lewin-Koh, N.J.I.; Chou, L.M. Genotype $\times$ environment interactions in transplanted clones of the massive corals Favia speciosa and Diploastrea heliopora. Mar. Ecol. Prog. Ser. 2004, 271, 167-182. [CrossRef]

94. Broadwell, M.M. Teaching for learning (XVI). Gospel Guard. 1969, 20, 1a-3a.

95. Mayer, I.; Wolff, A.; Wenzler, I. Learning efficacy of the 'Hazard Recognition' serious game: A quasi-experimental study. In Serious Games Development and Applications, 1st ed.; Ma, M., Oliveira, M.F., Petersen, S., Hauge, J.B., Eds.; Springer: Berlin/Heidelberg, Germany, 2013; Volume 8101, pp. 118-129.

96. Kolb, D.A. Experiential Learning: Experience as the Source of Learning and Development; Prentice-Hall: Englewood Cliffs, NJ, USA, 1984.

97. Kolb, D.A. The Learning Style Inventory: Technical Manual; McBer \& Co.: Boston, MA, USA, 1976.

98. Nenzhelele, T.E. Employability through experiential learning course in open distance learning institution. Mediterr. J. Soc. Sci. 2014, 5, 1602-1612. [CrossRef]

99. Davis, L. Competence as situationally appropriate conduct: An overarching concept for lawyering, leadership, and professionalism. Santa Clara Law Rev. 2012, 52, 725-793.

100. Valiente, O.; Capsada-Munsech, Q.; de Otero, J.P.G. Educationalisation of youth unemployment through lifelong learning policies in Europe. Eur. Educ. Res. J. 2020, 19, 525-543. [CrossRef]

101. Heyes, J. Vocational training, employability and the post-2008 jobs crisis: Responses in the European Union. Econ. Ind. Democr. 2013, 34, 291-311. [CrossRef]

102. Sharma, H. The nexus between future of work and future of higher education: Redefining employability in the 21 st century. Medienimpulse 2020, 58. [CrossRef]

103. Mattick, K.; Gallen, D. Judging competence, providing feedback and changing organisations. Med. Educ. 2020, 54, 497-499. [CrossRef]

104. Van Ginkel, S.; Gulikers, J.; Biemans, H.; Mulder, M. The impact of the feedback source on developing oral presentation competence. Stud. High. Educ. 2017, 42, 1671-1685. [CrossRef]

105. Tymon, A. The student perspective on employability. Stud. High. Educ. 2013, 38, 841-856. [CrossRef]

106. Gerken, M.; Beausaert, S.; Segers, M. Working on professional development of faculty staff in higher education: Investigating the relationship between social informal learning activities and employability. Hum. Resour. Dev. Int. 2016, 19, 135-151. [CrossRef] 
107. Wells, J.C. Leading organizational learning. HCA Healthc. J. Med. 2021, 2, 29-33. [CrossRef]

108. Audia, P.; Greve, H. Organizational Learning from Performance Feedback: A Behavioral Perspective on Multiple Goals: A Multiple Goals Perspective (Elements in Organization Theory), 1st ed.; Cambridge University Press: Cambridge, UK, 2021. [CrossRef]

109. Wiśniewska, S. Development of employee competencies as a determinant of employability in the modern labor market. Hum. Resour. Manag. 2015, 6, 131-143.

110. De Grip, A. The importance of informal learning at work. IZA World Labor 2015, 162. [CrossRef]

111. Raja, R.; Nagasubraman, P.C. Impact of modern technology in education. J. Appl. Adv. Res. 2018, 3 (Suppl. 1), S33-S35. [CrossRef]

112. Singh, A.; Singh, L.B. E-learning for employability skills: Students perspective. Procedia Comput. Sci. 2017, 122, 400-406. [CrossRef]

113. Levy, Y.; Ramim, M.M. An assessment of competency-based simulations on e-learners' management skills enhancements. Interdiscipl. J. eSkills Lifelong Learn. 2015, 11, 179-190. [CrossRef]

114. Çakmak, Z.; Akgün, I.H. A theoretical perspective on the case study method. J. Educ. Learn. 2018, 7, 96-102. [CrossRef]

115. Lucas, P.; Fleming, J.; Bhosale, J. The utility of case study as a methodology for work-integrated learning research. Int. J. Work Integr. Learn. 2018, 19, 215-222. 